\title{
Media Pembelajaran Flashcard Untuk Meningkatkan Kemampuan Mengenal Angka 1-10 Pada Siswa TK
}

\author{
Ines Lestari Simamora ${ }^{1 *}$, Wiyun Philipus Tangkin ${ }^{2}$ \\ ${ }^{1} \mathrm{SDH}$ Kupang, Indonesia \\ ${ }^{2}$ Universitas Pelita Harapan, Indonesia \\ *Coresponding Author: lestariines21@gmail.com
}

Article History:

Received 2021-11-08

Revised 2021-12-18

Accepted 2022-01-30

DOI:

10.31949/educatio.v8i1.1674

\begin{abstract}
Mathematic is a part of daily lives so it is important to learn. The most basic mathematical concept is recognized numbers. Every childhood is very important in learning this main concept because it can be useful in the next life. Based on the observation in mathematic subject, found that ablity of K2A students' numbers to recognize 1-10 still needs to improve. It can be seen through interview with mentor teacher to clarify the problems in class. The purpose of this research is to enbance numbers 1 10 recognition ability of students by using flashcard learning media. The Models of this Classroom Action Research is Pelton's models consisting of five stages through three activations. Instruments used in this research were Lessons plan, Mentor's feedback, Reflection journal Written test sheet, and Interview sheets (mentor). The result of the research showed the ability to recognize numbers 1-10 increased on all research subjects. The indicator mentions the sequence of numbers 1-10 and calculates the number of images 1-10 achieved by all research subjects. The indicator connects/matches the number of images with number can be achieved by all research subjects, although not all of the research subjects recognized numbers 1-10 as a whole. The result of the research also showed that the steps of using flashcard learning media with modified by game method have been done align with Lessons plan, Mentor's feedback, and Reflection journal. Thus, it can be concluded that the use of flashcard learning media can enhance numbers 1-10 recognition ability of kindergarten students at Manado.
\end{abstract}

Keywords: learning media; flashcard media; numbers 1-10 recognition ability

\section{Abstrak}

Matematika merupakan bagian dari kehidupan sehari-hari sehingga penting untuk dipelajari. Konsep matematika yang paling dasar adalah mengenal angka. Anak usia dini penting sekali diajarkan konsep utama ini, karena akan berguna untuk kehidupan selanjutnya. Berdasarkan hasil observasi pada mata pelajaran matematika ditemukan bahwa kemampuan mengenal angka 1-10 pada siswa K2A masih perlu diperbaiki. Hal ini terlihat dari wawancara kepada guru mentor, untuk mengklarifikasi masalah yang terjadi di dalam kelas. Tujuan dari penelitian ini adalah untuk meningkatkan kemampuan mengenal angka 1-10 dengan menggunakan media pembelajaran flashcard. Model Penelitian Tindakan Kelas yang digunakan adalah model Pelton yang terdiri atas lima tahap melalui tiga tindakan. Adapun instrumen yang digunakan adalah Rancangan Pelaksanaan Pembelajaran (RPP), Umpan balik mentor, Jurnal refleksi peneliti, Lembar tes siswa, dan Wawancara (guru mentor). Hasil penelitian menunjukkan kemampuan mengenal angka 1-10 meningkat. Indikator menyebutkan urutan angka 1-10 dan menghitung jumlah gambar 1-10 telah dicapai. Indikator menghubungkan/mencocokkan jumlah gambar dengan angka dapat dicapai oleh seluruh subyek penelitian. Hasil penelitian juga menunjukkan bahwa langkah-langkah penggunaan media pembelajaran flashcard yang dimodifikasi dengan metode bermain telah dilaksanakan sesuai dengan RPP, umpan balik mentor, dan jurnal refleksi. Dengan demikian dapat disimpulkan bahwa penggunaan media pembelajaran flashcard dapat meningkatkan kemampuan mengenal angka 1-10 pada siswa TK di Manado.

Kata Kunci: media pembelajaran; media flashcard; kemampuan mengenal angka 1-10 


\section{PENDAHULUAN}

Pendidikan sebagai salah satu alat yang digunakan untuk mendidik murid dan mengembangkan potensi yang dimiliki oleh setiap murid (Neolaka \& Neolaka, 2017). Pendidikan merupakan hal yang penting untuk menunjang kehidupan manusia dan sudah dimulai sejak dini. Pendidikan anak usia dini merupakan salah satu bentuk penyelenggaraan pendidikan yang meletakkan dasar ke arah pertumbuhan dan perkembangan fisik, kecerdasan, sosio emosional, bahasa, sesuai dengan perkembangan yang dimiliki setiap anak (Sujiono, 2013).Anak usia dini adalah individu yang sedang mengalami perkembangan yang pesat. Anak usia dini berada dalam rentang usia 0-8 tahun dan dalam masa keemasan (golden age) (Sujiono, 2013). Anak-anak pada usia ini sedang berada di fase pra-operasional. Tahap ini merupakan masa permulaan bagi anak, untuk membangun kemampuannya dan mempunyai andil yang besar bagi perkembangan kognitif anak (Jamaris, 2006).

Pengembangan aritmatika adalah salah satu perkembangan kognitif yang sedang dialami anak usia dini dan diarahkan untuk kemampuan matematika. Kemampuan matematika berhubungan dengan mengenali atau membilang angka, menyebut urutan bilangan, menghitung jumlah benda, membilang benda, menghubungkan konsep bilangan dengan lambang bilangan (Hatini, 2012; Khadijah, 2016; Rahman \& Fuadatun, 2017). Matematika adalah bagian penting dalam pendidikan dasar dan pasti dijumpai dalam kegiatan sehari-hari. Misalnya, ketika ingin membeli sesuatu penting untuk mengetahui konsep berhitung dan mengenali angka agar dapat mengenali nilai mata uang.

Kemampuan matematika yang paling mendasar adalah mengenali angka (Haslana \& Wirastania, 2017; Miswara et al, 2018; Stiawan \& Mustaqimah, 2021). Di tingkat pra-TK hingga kelas 2 semua siswa harus: mengurutkan, mengklasifikasikan, dan menata benda berdasarkan ukuran, mengenali angka, mendeskripsikan angka, dan memperluas pola seperti urutan bunyi dan bentuk atau pola numerik sederhana (Morrison, 2012). Menurut Depdiknas tahun 2004, Kurikulum 2004 Standar Kompetensi TK/RA menyebutkan beberapa indikator tentang kemampuan matematika anak usia 4-6 tahun yaitu membilang/menyebut urutan bilangan dari 1-20, membilang (mengenal) konsep bilangan dengan benda-benda sampai 10, menghubungkan/memasangkan lambang bilangan dengan benda-benda sampai 10, dll., (Susanto, 2011). Beberapa indikator inilah yang seharusnya sudah bisa dipenuhi oleh anak usia 4-6 tahun.

Berdasarkan observasi dan pengajaran yang peneliti lakukan pada siswa TK di Manado masih terdapat beberapa anak yang belum mengenal angka dan belum bisa menghubungkan angka dengan jumlah benda. Hal ini terlihat ketika siswa diminta untuk menunjukkan angka 1-10, terdapat 5 dari 22 siswa masih belum bisa menunjukkan angka yang benar. Ketika diminta menghubungkan jumlah angka dengan gambar, 5 siswa tersebut juga masih kesulitan untuk mengerjakannya. Dalam pembelajaran matematika untuk anak TK, materi yang disampaikan adalah mengenal angka dan menghitung jumlah gambar. Penggunaan media yang berkaitan dengan angka berada di dalam kelas dan belum digunakan dengan efektif. Media tersebut ditempel di sisi kiri kelas dengan posisi yang tinggi sehingga siswa sulit untuk melihat media yang berisi angka tersebut. Berdasarkan pemaparan di atas jelas bahwa kemampuan mengenal angka 1-10 pada siswa TK di Manado masih perlu diperbaiki. Anak usia taman kanak-kanak sangat membutuhkan media berupa visual untuk membantu mereka mengenali angka. Media visual berupa flashcard (kartu angka) adalah media pembelajaran berupa gambar atau foto yang disajikan keterangan pada setiap gambar (Chandra, 2017; Nurseto, 2011; Rofi'ah et al, 2018). Media flashcard diharapkan dapat membantu anak dalam mengenali angka 1-10 pada siswa TK di Manado.

Berdasarkan latar belakang yang telah diuraikan oleh peneliti di atas, maka permasalahan yang akan dibahas pada penelitian ini adalah: Apakah media pembelajaran flashcard dapat meningkatkan kemampuan mengenal angka 1-10 pada siswa TK di Manado?; Bagaimana media pembelajaran flashcard dapat meningkatkan kemampuan mengenal angka 1-10 pada siswa TK di Manado?. Berdasarkan rumusan masalah, maka tujuan dari penelitian ini adalah: Untuk mengetahui media pembelajaran flashcard dapat meningkatkan kemampuan mengenal angka 1-10 pada siswa TK di Manado. Untuk menjelaskan penggunaan media pembelajaran flashcard dapat meningkatkan kemampuan mengenal angka 1-10 pada siswa TK Manado. Manfaat dari penelitian ini adalah sebagai salah satu solusi untuk mengatasi permasalahan siswa terkait pengenalan angka yang merupakan dasar dari pelajaran matematika. 
Adapun indikator yang diambil oleh peneliti adalah menyebutkan angka 1-10 secara berurutan, menghitung jumlah gambar 1-10, dan menghubungkan/mencocokkan jumlah gambar dengan angka. Langkah-langkah penggunaan media flashcard oleh peneliti yaitu media flashcard ditunjukkan kepada seluruh siswa, siswa diberikan pertanyaan tentang angka yang terdapat pada flashcard, flashcard ditunjukkan secara berurutan, siswa diberikan pertanyaan tentang angka pada flashcard, siswa menghitung jumlah gambar pada flashcard, siswa melakukan permainan menggunakan media flashcard. Permainan yang dilakukan terdiri dari 3 orang, siswa akan berlari dan menyentuh flashcard sesuai dengan angka yang disebutkan.

\section{METODE PENELITIAN}

Penelitian ini menggunakan model penelitian tindakan kelas model Pelton yang terdiri atas lima tahap melalui tiga tindakan. Lima tahapan dari model Pelton yaitu, 1) Identifikasi Masalah (Issue identification), 2) Pengumpulan Data (Data Collection), 3) Perencanaan Tindakan (Action Planning), 4) Pelaksanaan Rencana (Plan Activation), 5) Penilaian Hasil (Outcome Assessment). Penelitian ini dilaksanakan pada TK di Manado, dengan jumlah subyek penelitian sebanyak 5 siswa.

Instrumen yang digunakan adalah Rancangan Pelaksanaan Pembelajaran (RPP), Umpan balik mentor, Jurnal refleksi peneliti, Lembar tes siswa, dan Wawancara (guru mentor). Data yang terkumpul dianalisis secara deskriptif kualitatif.

\section{HASIL DAN PEMBAHASAN}

Berdasarkan penelitian yang dilakukan, peneliti menemukan berbagai masalah yang terdapat di dalam kelas. Masalah yang ditemukan disajikan dalam tabel 1.

Tabel 1. Identifikasi Masalah

\begin{tabular}{|c|c|c|}
\hline Hari ke- & Masalah yang ditemukan & Ranah \\
\hline 1 & $\begin{array}{l}\text { Sebagian besar siswa sudah bisa menghitung angka 1-10 tetapi terdapat beberapa siswa yang } \\
\text { belum mengenal angka } 1-10 \text {, khususnya angka yang sudah dipelajari yaitu angka } 1-3 \text {. }\end{array}$ & Kognitif \\
\hline 2 & Beberapa siswa belum mengenal angka 1-5, namunbisa menghitung angka 1-5 dengan benar. & Kognitif \\
\hline 3 & $\begin{array}{l}\text { Pada saat dilakukan kegiatan permainan menemukan angka } 7 \text { dan membuat garis di bawah } \\
\text { angka } 7 \text {, masih terdapat siswa yang belum mampu menemukannya karena belum mengenal } \\
\text { angka tersebut. }\end{array}$ & Kognitif \\
\hline 4 & $\begin{array}{l}\text { Pada saat dilakukan permainan menggunakan media akuarium dan ikan, hampir seluruh } \\
\text { siswa menempel } 10 \text { ikan ke dalam akuarium sedangkan yang diminta hanya } 8 \text { ikan. }\end{array}$ & Kognitif \\
\hline 5 & $\begin{array}{l}\text { Sebagian besar siswa sudah bisa menyusun } 9 \text { lego yang diinstruksikan oleh guru, namun } \\
\text { masih terdapat siswa yang belum bisa menyusunnya sampai } 9 \text {, dikarenakan belum bisa } \\
\text { menghitung angka } 1-9 \text {. }\end{array}$ & Kognitif \\
\hline 6 & $\begin{array}{l}\text { Ketika diberikan lembar kerja tentang menghubungkan angka dengan gambar yaitu angka 6- } \\
\text { 10, masih terdapat beberapa siswa yang belum bisa menghubungkan angka dengan gambar. } \\
\text { Hal ini disebabkan siswa tersebut belum bisa mengenal angka 6-10. }\end{array}$ & Kognitif \\
\hline \multicolumn{3}{|c|}{$\begin{array}{l}\text { Masalah utama yang } \\
\text { ditemukan }\end{array}$} \\
\hline
\end{tabular}

Identifikasi masalah menggunakan sumber data antara lain, RPP, Umpan balik mentor, Jurnal refleksi peneliti, dan Wawancara. Masalah yang ditemukan terlihat dari 7 kali pertemuan pada pelajaran matematika. Pembelajaran tersebut dimulai dari angka 3, 4, review angka 1-5, angka 7, 8, 9, review 6-10, dan review angka 1-10. Berdasarkan RPP tentang mengulang kembali pembelajaran 6-10 dituliskan bahwa diagnosa ranah kognitif, beberapa siswa masih sulit dalam mengenal angka 1-9. Sedangkan dalam jurnal refleksi, peneliti juga dijelaskan bahwa terdapat siswa yang masih belum mengenal angka 1-10. Hal ini terlihat ketika siswa diinstruksikan untuk menunjuk angka sesuai dengan instruksi guru, terdapat beberapa siswa yang belum bisa dikarenakan belum mengenal angka. Permasalahan yang terjadi di kelas juga didukung oleh umpan balik mentor yang 
mengatakan bahwa tidak semua siswa di dalam kelas dapat mengenal angka dengan benar seperti AL, DA, EL, JO, dan KE (inisial nama siswa).

Selain instrumen tersebut, dari hasil observasi berupa ceklis terhadap pengenalan siswa tentang angka 110, terkonfirmasi bahwa 5 dari 22 siswa belum mengenal angka. Dari hasil wawancara dengan guru, terkait dengan permasalahan yang terjadi di kelas yaitu kemampuan mengenal angka 1-10, terkonfirmasi juga kelima siswa tersebut belum memilika kemampuan dalam pengenalan angka 1-10. Berdasarkan identifikasi masalah beserta sumber data yang sudah dijelaskan di atas, dapat disimpulkan permasalahan yang terjadi adalah 5 dari 22 siswa belum mengenal angka 1-10. 5 siswa ini merupakan subyek penelitian.

Sebelum melakukan pembelajaran, peneliti sudah merencanakan kegiatan yang akan dilakukan dengan media flashcard yang tertuang di RPP. Berdasarkan diagnosa dalam ranah kognitif di RPP mengatakan bahwa beberapa siswa masih belum bisa mengenal angka dan masih sulit dalam mencocokkan jumlah gambar dengan angka. Dengan demikian, maka tujuan pembelajaran yaitu menyebutkan urutan angka 1-10, menghitung jumlah gambar pada flashcard dan mencocokkan jumlah gambar dengan angka melalui lembar kerja. Berikut ini langkah-langkah penggunaan media flashcard yang dilaksanakan pada pertemuan pertama.

Tabel 2. Kegiatan Pembelajaran 1

\begin{tabular}{clc}
\hline No. & \multicolumn{1}{c}{ Kegiatan } & Waktu \\
\hline 1. & Menyampaikan tujuan pembelajaran, memberikan motivasi berupa video tentang angka, dan & 5 menit \\
& mengulang kembali pembelajaran tentang angka 1-10 & 50 menit \\
2. & Flashcard ditunjukkan kepada seluruh siswa (secara berurutan lalu acak) & \\
3. & Siswa menyebutkan angka yang terdapat pada flashcard. & \\
4. & Siswa menghitung jumlah gambar yang terdapat pada flashcard. (Guru fokus kepada 5 siswa) \\
5. & Siswa mencocokkan/ menghubungkan jumlah gambar dengan angka menggunakan flashcard di \\
& papan tulis. (Fokus kepada 5 siswa) & \\
6. & Siswa mengerjakan lembar kerja yang dibagikan oleh guru tentang mencocokkan angka 1-10. \\
\hline
\end{tabular}

Pembelajaran dimulai dengan mendengarkan video, mengulang kembali pembelajaran dengan menggunakan media flashcard. Media flashcard dipegang setinggi dada kemudian flashcard disusun secara berurutan dan meminta siswa untuk menyebutkan angka yang sesuai dengan flashcard. Setelah berurutan, flashcard diacak dan ditunjukkan kepada siswa serta siswa menyebutkan angka yang sesuai. Siswa kemudian menghitung jumlah gambar yang terdapat pada flashcard, siswa juga diinstruksikan untuk mencocokkan jumlah gambar dengan angka di papan tulis. Siswa mengerjakan lembar kerja yang diberikan guru. Dalam umpan balik mentor, peneliti mengasumsikan bahwa ketika siswa mengenal 1 angka maka akan terhitung 10\% dan jika siswa mengenal angka secara keseluruhan yaitu 1-10 maka akan terhitung 100\%. Berikut ini akan disajikan tabel umpan balik mentor terhadap kemampuan mengenal angka 1- 10.

Tabel 3. Hasil Lembar Umpan Balik Mentor Terhadap Kemampuan Mengenal Angka 1-10

\begin{tabular}{ll}
\hline Inisial & \multicolumn{1}{c}{ Pengenalan Angka Melalui Media Pembelajaran Flashcard } \\
\hline AL & $\begin{array}{l}\text { Al masih kesulitan dalam mengenal angka sehingga hanya mengenal angka 1.Pengenalan angka yang } \\
\text { dicapai oleh AL adalah } 10 \% .\end{array}$ \\
DA & $\begin{array}{l}\text { DA yang tidak bisa mengerjakan lembar kerja karena belum mengenal angka1-10.Pengenalan angka } \\
\text { yang dicapai oleh DA adalah } 0 \% .\end{array}$ \\
EL & $\begin{array}{l}\text { EL juga menunjukkan perkembangan karena dapat menghubungkan angka 1, 2, 6-9. Pengenalan angka } \\
\text { yang dicapai oleh EL yaitu } 60 \% .\end{array}$ \\
JO & JO yang sudah mengenal angka 1, 7, dan 10. Pengenalan angka yang dicapaioleh JO yaitu 30\%. \\
KE & $\begin{array}{l}\text { KE sudah mulai menunjukkan perkembangan dengan mengenal angka 1. Pengenalan angka yang } \\
\text { dicapai oleh KE adalah } 10 \% .\end{array}$ \\
\hline
\end{tabular}

Berikut pengenalan angka 1-10 melalui media pembelajaran flashcard. 
Tabel 4. Jurnal Refleksi Peneliti Terhadap Kemampuan Mengenal Angka 1-10

Inisial Pengenalan Angka Melalui Media Pembelajaran Flashcard

AL AL hanya mengenal angka 1 ketika diminta untuk menyebutkan angka dan menghitung jumlah benda.

AL harus dibantu dalam pengerjaan lembar kerja. Jika tidak dibantu, ia terus bertanya. Pengenalan angka yang dicapai oleh AL adalah 10\%.

DA DA, tidak menjawab pertanyaan peneliti ketika peneliti memintanya menyebutkan angka dan menghubungkan angka. DA menangis karena malu dan tidak bisa menyebutkannya. DA juga tidak bisa mengerjakan lembar kerjanya sama sekali dan terlihat ketika peneliti datang dan ia belum mengerjakannya. Ia mengaku tidak bisa mengerjakannya. Setelah dibantu, ia bisa menjawab angka 1, 2, 3. Pengenalan angka yang dicapai oleh DA adalah $0 \%$.

EL EL hanya bisa mengenal angka 1, sehingga ketika menghubungkan angka di papan tulis ia hanya bisa menghubungkan jumlah gambar dengan angka 1. Meskipun, EL dalam pengerjaan lembar kerja dapat menghubungkan beberapa angka seperti 1, 2, 6, 7, 8, 9, namun dengan bantuan dari guru yang mengajar. Sebenarnya, jika tanpa dibantu EL hanya mampu menghubungkan angka 1 karena hanya angka tersebut yang ia kenali. Pengenalan angka yang dicapai oleh EL adalah $10 \%$.

JO JO yang mampu menyebutkan angka 1, 7, dan 10, ketika media berisi angka ditunjukkan. JO tidak perlu bantuan peneliti dalam mengerjakan lembar kerja. Hal itu terlihat ketika peneliti datang di saat JO mengerjakan lembar kerja. Pengenalan angka yang dicapai oleh 30\%.

KE KE hanya mengenal angka 1. Di dalam pengerjaan lembar kerja KE masih dibantu, dan jika tidak maka ia tidak dapat mengerjakannya. Pengenalan angka yang dicapai oleh KE adalah $10 \%$.

Di awal pembelajaran peneliti menginstruksikan siswa untuk menyebutkan angka secara berurutan. AL, EL, dan DA masih ragu dalam menyebutkannya. Sedangkan untuk JO dan KE sudah mampu menyebutkannya beberapa angka dengan benar. Ketika di acak dan meminta mereka menyebutkan angka sesuai flashcard, mereka sama sekali belum bisa menyebutkannya dengan benar. Setelah menyebutkan, peneliti menginstruksikan siswa untuk menghitung jumlah gambar yang terdapat pada flashcard yang ditunjukkan, tetapi kelima siswa belum bisa menghitung jumlah gambar dengan benar.

Lembar tes siswa digunakan pada setiap pertemuan ketika media flashcard digunakan. Dalam penilaian ini siswa yang dapat menghubungkan jumlah gambar dengan angka dengan benar akan dihitung 10\% untuk satu soal. Di dalam lembar kerja terdapat 10 soal, sehingga ketika siswa dapat menghubungkan jumlah gambar dengan angka maka akan terhitung 100\%. Seperti yang sudah dijelaskan di dalam jurnal refleksi bahwa lembar kerja AL, DA, EL, dan KE dibantu oleh peneliti untuk mengerjakannya. Hasil dari tes pada pertemuan pertama sampai pertemuan ketiga dapat dilihat pada tabel 5.

Tabel 5. Hasil Tes Siswa Pertemuan 1

\begin{tabular}{lcc}
\hline No. & Inisial Siswa & Nilai \\
\hline 1. & AL & Keep it up $(10 \%)$ \\
2. & DA & Keep it up $(30 \%)$ \\
3. & EL & Well Done $(40 \%)$ \\
4. & JO & Nice Try $(50 \%)$ \\
5. & KE & Keep it up $(30 \%)$ \\
\hline
\end{tabular}

Penggunaan media flashcard kedua kalinya. Perencanaan pembelajaran tertuang di dalam RPP. Diagnosa dalam ranah kognitif mengatakan bahwa masih terdapat siswa belum mampu menyebutkan bilangan 1-10 secara berurutan, menghitung jumlah gambar 1-10 dan dalam pengerjaan lembar kerja masih terdapat siswa yang kesulitan dalam mengenal angka sehingga tidak maksimal ketika mengerjakannya. Sehingga tujuan pembelajaran pada pertemuan ini, yaitu menyebutkan urutan angka 1-10, menghitung jumlah benda 1-10, dan mencocokkan/menghubungkan jumlah gambar dengan angka pada flashcard. Berikut langkah-langkah pembelajaran dengan menggunakan media flashcard:

Berdasarkan hasil pengamatan pada tabel 6, seluruh siswa sudah terlibat di dalam pembelajaran menggunakan media flashcard, pembelajaran menarik dan menyenangkan sehingga memberikan nilai positif bagi siswa. Siswa juga semakin bersemangat dari sebelumnya. Di dalam melakukan permainan, peraturan dan langkah-langkah yang harus dilakukan telah dijelaskan dengan baik. Hal yang harus diperbaiki yaitu 
memastikan media flashcard dapat tertempel dengan erat di sekitar ruangan kelas sehingga siswa dapat melaksanakan permainan dengan baik.

Tabel 6. Kegiatan Pembelajaran 2

\begin{tabular}{cll}
\hline No. & \multicolumn{1}{c}{ Kegiatan } & Waktu \\
\hline 1. & Menyampaikan tujuan pembelajaran memberikan motivasi secara verbal,dan mengulang & 5 menit \\
2. & kembali pembelajaran sebelumnya. & 50 menit \\
3. & Flashcard ditunjukkan kepada seluruh siswa & \\
4. & Siswa menyebutkan angka yang sesuai dengan flashcard (Guru mengamati 5siswa) \\
5. & Siswa diberikan pertanyaan tentang angka 1-10 pada media flashcard. \\
6. & Siswa diminta untuk menghitung jumlah kursi yang ada di kelas danmenunjukkan flashcard \\
& yang sesuai dengan jumlah kursi tersebut. \\
7. & Siswa mendengarkan penjelasan guru tentang peraturan permainan \\
8. & Siswa dipilih secara acak masing-masing 3 orang \\
9. & Siswa mendengarkan angka yang disebutkan oleh guru \\
10. & Siswa berlari dan menyentuh angka yang sesuai dengan apa yang disebutkanoleh guru & \\
& (Permainan dilakukan sampai seluruh siswa mendapatkan giliran) \\
11. & Siswa mengisi lembar kerja yang diberikan oleh guru \\
\hline
\end{tabular}

Cara mengerjakan lembar kerja harus lebih jelas karena terdapat siswa yang masih bingung sehingga membutuhkan bimbingan secara individu untuk mengerjakannya. Instruksi permainan juga sudah cukup jelas disampaikan. Dalam menyampaikan instruksi lembar kerja, peneliti perlu mengecek siswa sudah mengerti atau belum dalam mengerjakannya.

Tabel 7. Umpan Balik Guru Mentor Terhadap Kemampuan Mengenal Angka 1-10

\begin{tabular}{ll}
\hline Inisial & \multicolumn{1}{c}{ Pengenalan Angka Melalui Media Pembelajaran Flashcard } \\
\hline AL & $\begin{array}{l}\text { AL baru mengenal angka } 3 \text { dari sebelumnya belum mengenal angka samasekali. Pengenalan angka yang } \\
\text { dicapai AL adalah 10\%. }\end{array}$ \\
DA & $\begin{array}{l}\text { DA juga masih kesulitan dalam mengenal angka 1-10 terlihat ketika ia kebingungan memilih angka yang } \\
\text { sesuai dengan yang disebutkan oleh guru.Pengenalan angka yang dicapai oleh DA adalah } 0 \% .\end{array}$ \\
EL & Tidak ada komentar terhadap EL. \\
JO & JO yang menunjukkan perkembangan dan sudah mengenal angka 2, 3, 9, dan 10. Pengenalan angka yang \\
KE & KE sudah mengenal angka dengan baik sewaktu permainan dilakukan. \\
\hline
\end{tabular}

Di awal pembelajaran, peneliti menjelaskan tujuan pembelajaran, mengulang kembali pembelajaran sebelumnya dengan menyebutkan urutan angka 1-10, dan menjelaskan permainan yang akan dilakukan. Media flashcard ditempel di seluruh ruangan kelas dan meminta seluruh siswa menyebutkan angkanya secara cepat. Penggunaan media flashcard yang disertai dengan permainan, yaitu pertama siswa ditunjukkan media flashcard yang akan digunakan, siswa menyebutkan angka yang sesuai dengan flashcard, siswa menghitung jumlah benda, siswa mendengarkan penjelasan tentang permainan yang akan dilakukan yaitu ketika angka disebutkan maka siswa yang sudah dipilih secara acak dan terdiri atas 3 orang akan berlari dan menyentuh flashcard sesuai dengan yang disebutkan. Setelah bermain, siswa dibagikan lembar kerja. Umpan balik mentor terhadap kemampuan mengenal angka 1-10 pada pertemuan kedua disajikan dalam tabel 7 .

Tabel 8. Hasil Tes Siswa Pertemuan 2

\begin{tabular}{ccc}
\hline No. & Inisial Siswa & Nilai \\
\hline 1 & AL & Keep it up $(20 \%)$ \\
2 & DA & Keep it up $(40 \%)$ \\
3 & EL & Keep it up $(10 \%)$ \\
4 & JO & Well done $(70 \%)$ \\
5 & KE & Keep it up $(70 \%)$ \\
\hline
\end{tabular}


Sebelum melakukan permainan, peneliti meminta siswa untuk menyebutkan urutan angka 1-10 dan menghitung jumlah gambar yang terdapat pada flashcard. Subyek penelitian sudah dapat menyebutkan urutan angka 1-10 dengan benar dan sudah mampu menghitung jumlah gambar yang terdapat pada flashcard dengan benar. Hasil tes siswa pada pertemuan kedua menggunakan media pembelajaran flashcard diterapkan dapat dilihat pada tabel 8.

Pada RPP, diagnosa kelima siswa masih sulit dalam mengenal/mengidentifikasi dan menghubungkan jumlah gambar dengan angka. Oleh karena itu tujuan pembelajaran adalah menghitung jumlah gambar pada media flashcard dan mencocokkan jumlah gambar dengan angka melalui lembar kerja. Langkah-langkah pembelajarandengan menggunakan media flashcard dapat dilihat pada tabel 9.

Tabel 9. Kegiatan Pembelajaran 2

\begin{tabular}{cll}
\hline No. & \multicolumn{1}{c}{ Kegiatan } & Waktu \\
\hline 1. & Menyampaikan tujuan pembelajaran, menyampaikan motivasi secaraverbal, dan & 5 menit \\
& mengulang kembali pembelajaran sebelumnya dengan media flashcard. & \\
2. & Siswa mendengarkan penjelasan guru tentang permainan yang akandilakukan & 50 menit \\
3. & Siswa memperhatikan letak kartu yang disusun di lantai & \\
4. & Siswa dipanggil masing-masing 3 orang untuk melakukan permainan & \\
5. & Siswa mendengarkan angka yang disebutkan oleh guru & \\
6. & Siswa berlari ke arah angka yang disebutkan dan berdiri didepan angka tersebut & \\
7. & Siswa mengerjakan lembar kerja yang dibagikan oleh guru & \\
\hline
\end{tabular}

Permainan yang digunakan dalam pembelajaran tidak jauh berbeda dengan permainan flashcard sebelumnya. Media flashcard ditempelkan di lantai secara berurutan dan ketika angka disebutkan, maka siswa akan berlari dan berdiri di depan angka tersebut. Pada saat mengikuti pembelajaran ini, semangat siswa berkurang dikarenakan permainan yang diterapkan sudah sering. Masukan untuk pembelajaran selanjutnya adalah menggunakan media yang sama namun dengan metode yang berbeda. Namun dari media yang sudah dilakukan dapat membantu siswa dalam menyelesaikan lembar kerja yang diberikan.

Peneliti memulai pembelajaran dengan mengulang kembali pembelajaran sebelumnya tentang mengenal angka 1-10. Setelah itu, peneliti menjelaskan peraturan permainan yang akan dilakukan. Permainan yang akan dilakukan juga tidak berbeda jauh dengan sebelumnya, hanya kali ini siswa tidak lagi menyentuh flashcard melainkan berdiri di depan flashcard yang sudah disusun di lantai. Permainan dilakukan sampai seluruh siswa mendapat giliran. Setelah siswa melakukan permainan, peneliti membagikan lembar kerja tentang menghubungkan/mencocokkan jumlah gambar dengan angka. Umpan balik mentor terhadap kemampuan mengenal angka 1-10 disajikan dalam tabel berikut ini:

Tabel 10. Umpan Balik Mentor Terhadap Kemampuan Mengenal Angka 1-10

\begin{tabular}{ll}
\hline Inisial & \multicolumn{1}{c}{ Pengenalan Angka Melalui Media Pembelajaran Flashcard } \\
\hline AL & AL masih kesulitan dan hanya mengenal angka 4. Pengenalan angka yangdicapai oleh AL adalah $10 \%$. \\
DA & DA hanya mengenal angka 4. Pengenalan angka yang dicapai oleh DA adalah $10 \%$. \\
EL & EL mengenal angka 1. Pengenalan angka yang dicapai oleh EL adalah 10\%. \\
JO & JO mengenal angka dengan baik dan pergi ke angka 1, 2, 3, 9, dan 10, sesuai dengan yang disebutkan \\
& oleh guru. Pengenalan angka yang dicapai oleh JO adalah 50\%. \\
KE $\quad$ Tidak ada komentar terhadap KE.
\end{tabular}

Sebelum melakukan permainan, peneliti meminta subyek penelitian untuk menyebutkan angka 1-10 secara berurutan dan menghitung jumlah gambar yang terdapat pada media pembelajaran flashcard 1-10. Kelima subyek penelitian sudah mampu menyebutkan dan menghitungnya dengan benar. Hanya saja ketika dilakukan secara acak, masih terdapat siswa yang masih bingung untuk menyebutkan angka. 
Tabel 11 Jurnal Refleksi Peneliti Terhadap Kemampuan Mengenal Angka 1-10

\begin{tabular}{|c|c|}
\hline Inisial & Pengenalan Angka Melalui Media Pembelajaran Flashcard \\
\hline $\mathrm{AL}$ & $\begin{array}{l}\text { AL pada saat melakukan permainan berlari dan berdiri di depan angka yang salah. Ketika peneliti } \\
\text { bertanya secara lisan kepada AL, ia mampu menjawab pertanyaan peneliti dan menunjukkan angka } 3 \\
\text { dan } 10 \text {. Berdasarkan pengamatan peneliti, AL masih stabil ketika mengenal angka yaitu } 3 \text { dan } 10 . \\
\text { Berbeda ketika mengerjakan lembar kerja, AL melihat pekerjaan temannya. Saat mengetahui bahwa } \\
\text { AL berbuatdemikian, saya sebagai guru merasa sedih dan langsung menegur AL. Pengenalan } \\
\text { angka yang dicapai AL adalah } 20 \% \text {. }\end{array}$ \\
\hline DA & $\begin{array}{l}\text { DA mampu mengenal angka } 4 \text { dan } 10 \text {, hal ini terbukti ketika DA berlari dan berdiri di depan angka } \\
\text { tersebut sesuai dengan yang disebutkan oleh guru. Dalam pengerjaan lembar kerja, DA dibantu oleh } \\
\text { salah satu temannya yang memberikan jawaban secara keseluruhan. Namun, jika diberikan } \\
\text { pertanyaan secara lisan DA hanya mampu mengenal angka } 4 \text { dan } 10 \text {. Pengenalan angka yang dicapai } \\
\text { oleh DAadalah } 20 \% \text {. }\end{array}$ \\
\hline EL & $\begin{array}{l}\text { EL mampu mengenal angka } 1 \text { dan dari pertemuan sebelumnya EL masih mengenal angka } 1 \text {. EL } \\
\text { mampu menjawab beberapa pertanyaan dalam lembar kerja karena dibantu di dalam pengerjaannya. } \\
\text { Jika tidak, ia akan terus mengikuti peneliti dan memohon bantuan dalam menyelesaikan lembar } \\
\text { kerja. Pengenalan angka yang dicapai oleh EL adalah } 10 \% \text {. }\end{array}$ \\
\hline $\mathrm{JO}$ & $\begin{array}{l}\text { JO yang mampu mengenal angka dengan berlari dan berdiri di depan angka } 1,2,3 \text {, } 9 \text {, dan } 10 \text { sesuai } \\
\text { dengan yang disebutkan oleh guru. Berbeda dengan JO yang mampu mengenal angka 1, 2, 3, } 9 \text {, dan } \\
10 \text { ketika bermain dan berlari ke arah angka tersebut sesuai dengan perintah guru. Pengenalan angka } \\
\text { yang dicapai oleh JO adalah } 50 \% \text {. }\end{array}$ \\
\hline $\mathrm{KE}$ & $\begin{array}{l}\text { KE hanya berdiri dan berlari di depan angka } 5 \text { ketika permainan dilakukan. Dalam melakukan } \\
\text { permainan KE terlihat tidak percaya diri seperti sebelumnya KE terlihat ragu dalam melakukan } \\
\text { permainan. KE ketika diberikan pertanyaan secara lisan mampu memngenal angka meskipun belum } \\
\text { semuanya. Dalam lembar kerja, KE tidak dapat menghubungkan angka } 7,8 \text {, 9, dan } 10 \text {. Jika dilihat } \\
\text { dan diberikan pertanyaan, KE mampu menjawab dan mengenal angka } 1-5 \text { namun karena ia tidak } \\
\text { percaya diri maka ia ragu untuk berlari ke arah angka yang benar. Pengenalan angka yang dicapai } \\
\text { oleh KE adalah } 50 \% \text {. }\end{array}$ \\
\hline
\end{tabular}

Hasil tes siswa pada pertemuan ketiga menggunakan media pembelajaran flashcard dapat dilihat pada tabel 12.

Tabel 12. Hasil Tes Siswa Pertemuan 3

\begin{tabular}{ccc}
\hline No. & Inisial Siswa & Nilai \\
\hline 1 & AL & Excellent $(100 \%)$ \\
2 & DA & Well Done $(90 \%)$ \\
3 & EL & Nice Try $(60 \%)$ \\
4 & JO & Excellent $(100 \%)$ \\
5 & KE & Keep it up $(50 \%)$ \\
\hline
\end{tabular}

Wawancara dilakukan setelah media flashcard digunakan selama tiga kali. Wawancara ini bertujuan untuk melihat peningkatan yang dialami siswa terhadap kemampuan mengenal angka 1-10 melalui media flashcard. Dalam wawancara, guru mentor sebagai nara sumber menjelaskan bahwa media flashcard membantu siswa dalam mengenali angka karena disajikan secara visualisasi. Beberapa siswa juga mengalami peningkatan seperti JO dan KE yang mengenali beberapa angka walaupun masih perlu bantuan. Sedangkan untuk AL dan DA memang mengalami peningkatan walaupun tidak signifikan. AL dan DA memang membutuhkan bimbingan khusus secara individual.

Di dalam wawancara juga dijelaskan bahwa seluruh siswa termasuk subyek penelitian sudah mampu dalam menghitung jumlah gambar yang terdapat pada media pembelajaran flashcard. Siswa yang belum mengalami peningkatan secara signifikan merupakan unik dan memiliki batas kemampuan berbeda-beda sehingga memungkinkan untuk siswa ada yang bisa dalam mengenal angka dengan cepat dan ada juga yang tidak. Kemungkinan secara visual, menggunakan flashcard dapat membantu AL dan DA dalam mengingat dan memahami angka. Namun, untuk AL dan DA penggunaan media flashcard masih kurang dan melalui pembelajaran yang dilaksanakan dapat dilihat tidak adanya perubahan yang signifikan. AL dan DA memang perlu bimbingan khusus dan mungkin memerlukan metode yang lain seperti audio, memberikan pekerjaan rumah, dan bimbingan secara individual. 
Langkah-langkah penggunaan media pembelajaran flashcard yang telah dilaksanakan sebanyak 3 kali. Berdasarkan data tersebut dapat dilihat bahwa pada tindakan pertama peneliti tidak menggunakan flashcard dengan metode bermain, karena peneliti ingin fokus kepada indikator kemampuan mengenal angka yang harus dicapai siswa. Namun, dalam umpan balik mentor dituliskan bahwa siswa kurang bersemangat sehingga sulit dalam mengikuti pembelajaran. Merefleksi pembelajaran sebelumnya, akhirnya peneliti menggunakan metode bermain yang diharapkan mampu menarik perhatian siswa dalam mengikuti proses pembelajaran. Pada saat pelaksanaannya, peneliti melihat siswa menjadi sangat antusias dalam mengikuti pembelajaran. Pernyataan ini dikonfirmasi oleh mentor yang menuliskannya di dalam umpan balik guru mentor. Guru mentor menuliskan bahwa siswa sangat antusias dalam mengikuti pembelajaran dengan menggunakan permainan. Permainan yang diterapkan adalah berlari dan menyentuh flashcard yang berisi angka sesuai dengan instruksi. Ketika metode flashcard dilaksanakan dengan menggunakan permainan peneliti melihat bahwa permainan membuat siswa semakin semangat dalam mengikuti pembelajaran. Selain menyenangkan, bermain juga dapat meningkatkan kecerdasan anak (Darmadi, 2017).

Hal ini diiringi dengan kegiatan belajar sambil bermain sehingga ketika bermain siswa memperoleh pengetahuan yang baru. Selain itu, bermain juga dapat meningkatkan kepercayaan diri anak terkhusus jika dibantu dengan media (Sujiono, 2013). Hal senada juga diungkapkan oleh Masnipal (2013) bahwa dengan bermain dapat meningkatkan belajar anak, termasuk meningkatkan rasa percaya dirinya karena berinteraksi dengan lingkungan. Inilah yang menjadi pembelajaran baru bagi peneliti bahwa anak usia dini tidak terlepas dari hakikatnya yang masih senang dalam melakukan pembelajaran sambil bermain.

Pelaksanaan media pembelajaran flashcard yang diterapkan telah sesuai dengan RPP, Umpan balik, dan Jurnal refleksi peneliti, sehingga dapat disimpulkan bahwa pelaksanaan media pembelajaran flashcard sesuai dengan langkah-langkah yang diterapkan dapat meningkatkan kemampuan mengenal angka 1-10. Selain meningkatkan kemampuan mengenal angka, siswa juga semakin termotivasi dalam belajar karena dilakukan dengan permainan.

Peneliti menyadari bahwa di setiap pembelajaran yang dilakukan banyak kekurangan dan ketidaksempurnaan. Pada akhirnya peneliti dapat belajar dari kesalahannya dan memperbaiki pembelajaran agar tujuan pembelajaran dapat tercapai. Peneliti juga merefleksikan bahwa penggunaan media flashcard dilakukan agar siswa mampu mengenal angka 1-10. Media flashcard yang berisikan angka dan gambar membuat siswa lebih mudah mengenal angka. Selain itu, permainan flashcard juga mendorong siswa agar semangat belajar.

Indikator kemampuan mengenal angka 1-10 yaitu menyebutkan urutan angka 1-10, menghitung jumlah gambar 1-10, menghubungkan/mencocokkan jumlah gambar dengan angka yang dilakukan menggunakan media pembelajaran flashcard. Indikator pertama dan kedua dapat dilihat ketika siswa mampu menyebutkan urutan angka dan menghitung jumlah gambar. Selain itu, menghitung jumlah gambar juga bisa dilihat ketika siswa mampu menghubungkan jumlah gambar dengan angka pada lembar kerja. Pada saat siswa menjawab pertanyaan yang diajukan, peneliti dan guru mentor mengobservasi pemahaman mereka dan menuliskannya pada lembar umpan balik mentor dan jurnal refleksi peneliti. Berikut ini adalah grafik hasil tes siswa pada tindakan pertama sampai tindakan ketiga.

Gambar 1. menunjukkan pengenalan angka 1-10 meningkat dari sebelum diterapkannya media flashcard dan sesudah dilaksanakannya media flashcard. Sebelum media flashcard diterapkan, kelima siswa sebagai subyek penelitian, sama sekali belum mengenal angka. Hal ini dibuktikan dari instrumen pada identifikasi masalah yaitu lembar observasi yang dilakukan peneliti tentang pemahaman siswa terhadap angka, umpan balik mentor dan jurnal refleksi peneliti. Pencapaian ini juga terlihat dari indikator kemampuan mengenal angka. Indikator kemampuan mengenal angka tertuang dalam tujuan pembelajaran di RPP yang digunakan selama penerapan tindakan.

Pada tindakan pertama sampai kepada tindakan ketiga, tujuan pembelajaran mencakup 3 indikator mengenal angka 1-10. Dalam tindakan pertama, belum ada tujuan pembelajaran (indikator) yang tercapai, namun pada tindakan kedua tujuan pembelajaran menyebutkan urutan angka 1-10 dan menghitung jumlah gambar sudah tercapai dilihat dari jurnal refleksi peneliti. Tujuan pembelajaran menghitung dan 
menghubungkan angka tertulis pada RPP karena indikator tersebut saling berhubungan. Secara keseluruhan dapat disimpulkan bahwa setelah diterapkannya media flashcard, siswa dapat mengenal angka walaupun tidak semuanya karena hanya 1 siswa yang mengenal angka secara keseluruhan. Meskipun demikian hal ini memberikan pengaruh positif bagi siswa karena pada awalnya mereka belum mengenal angka sama sekali.

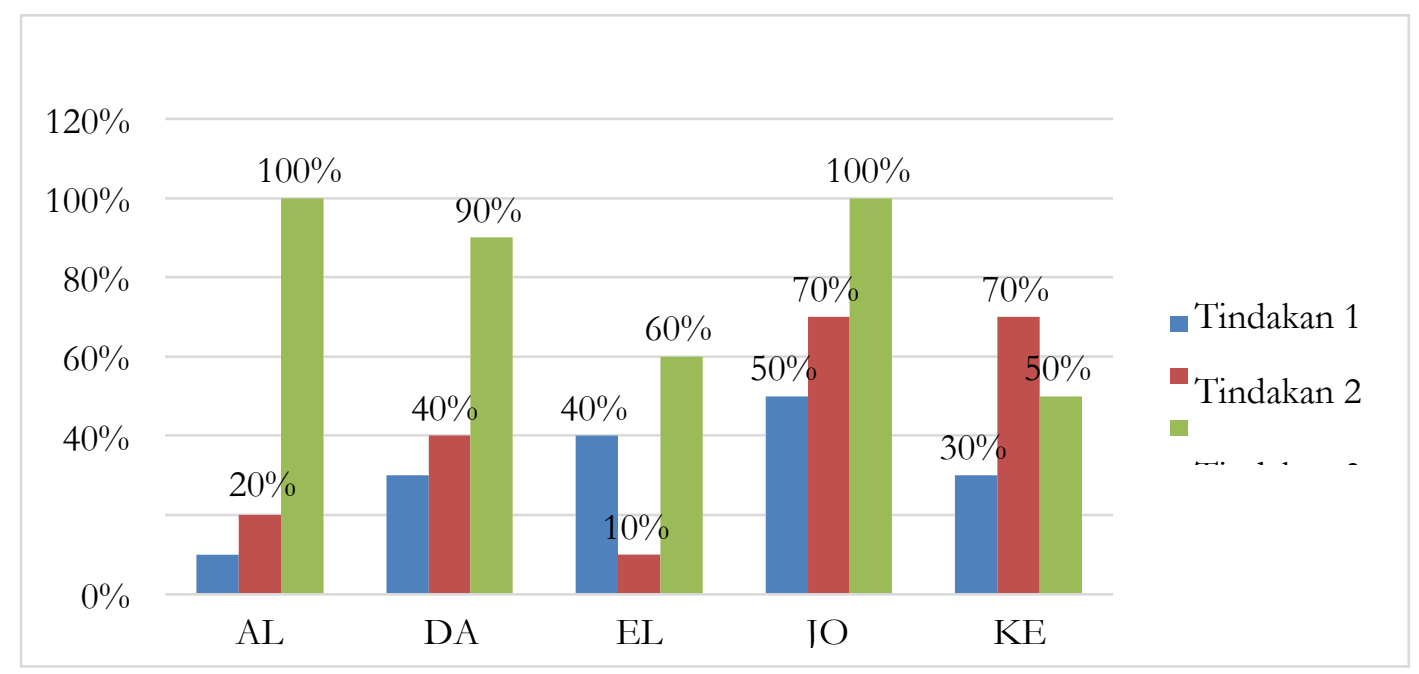

Gambar 1. Hasil tes siswa pada tindakan 1-3

Melalui diagram di atas, terlihat perkembangan siswa terhadap angka 1-10 dari tindakan pertama sampai tindakan ketiga. Namun, peningkatan yang terjadi tidak seluruhnya di alami oleh subyek penelitian. Dalam pengerjaan lembar kerja AL selalu dibantu oleh peneliti untuk mengerjakannya sehingga grafik di atas menunjukkan perkembangan yang signifikan khususnya di tindakan ketiga.

Namun, pada tindakan ketiga AL melihat pekerjaan temannya sehingga ia mampu menjawab soal pada lembar tes dengan baik. Secara keseluruhan penerapan yang dilakukan, AL hanya mengenal 3 angka yaitu 1, 3, dan 10. Perkembangan pengenalan angka ini dapat dilihat melalui umpan balik mentor dan jurnal refleksi peneliti. AL adalah seorang siswa yang aktif dalam dunia permodelan dan karena itu ia sering tidak masuk ke sekolah, sehingga membuat ia melewatkan beberapa pembelajaran. Orangtua AL juga seorang desainer dan sering melibatkan AL dalam pekerjaannya. Dengan ketidakhadiran AL di sekolah membuat ia tertinggal dan tidak mengikuti pembelajaran. Dalam hal inilah yang menjadikan AL juga belum mengenal angka secara keseluruhan.

Subyek penelitian DA selalu dibantu dalam mengerjakan lembar kerja. Dari penerapan pertama sampai ketiga, DA hanya mengenal 2 angka yaitu 4 dan 10. Peningkatan ini dapat dilihat melalui umpan balik mentor dan jurnal refleksi peneliti yang menuliskan kejadian yang terjadi selama proses pembelajaran berlangsung. DA adalah anak yang pemalu, terlihat ketika ia bersosialisasi selama di sekolah. Ia jarang sekali bermain dengan temannya dan lebih memilih duduk daripada bermain dengan teman. Motivasi sangat dibutuhkan untuk siswa seperti DA, karena setiap kali pembelajaran DA harus selalu didampingi agar DA mau mengerjakan apa yang diinstruksikan oleh guru. Motivasi merupakan kondisi seseorang untuk dapat melakukan sesuatu. Hal ini berlaku dalam kegiatan belajar, bahwa hasil belajar akan optimal bila adanya motivasi (Husamah, Pantiwati, Restian, \& Sumarsono, 2018). Motivasi yang diberikan oleh peneliti selama ini dalam bentuk verbal dan membantu DA dalam mengerjakan lembar kerja. Peneliti juga memberikan pujian sebagai penghargaan terhadap apa yang dilakukan DA terkait dengan pembelajaran mengenal angka.

EL tidak jauh berbeda dengan AL dan DA yang selalu dibantu dalam mengerjakan lembar kerja, sehingga grafik di atas menunjukkan peningkatan terhadap pengenalan angka. Namun, umpan balik mentor dan jurnal refleksi menunjukkan bahwa di pertemuan kedua dan ketiga EL hanya mengenal 1 angka. Peneliti mengamati perkembangan EL saat diterapkannya media flashcard dan melalui data yang diperoleh dari tindakan pertama sampai tindakan ketiga, EL hanya mengenal angka 1. Pada tindakan kedua, EL tidak 
mampu mengerjakan lembar kerja dikarenakan tidak mengikuti instruksi yang diberikan peneliti. Instruksi yang diberikan peneliti adalah melingkari angka yang sesuai dengan gambar. Namun pada pengerjaannya EL melingkari seluruh angka meskipun sudah dijelaskan secara individu.

EL berasal dari keluarga yang kedua orangtuanya sangat sibuk dengan pekerjaannya. Hal ini diketahui peneliti melalui interaksinya dengan EL dan ia merupakan siswa yang selalu lebih awal datang ke sekolah. Alasannya karena tidak ada teman bermain di rumah sebab orangtua pergi bekerja. Selama media flashcard diterapkan, EL satu-satunya yang mengenal 1 angka dan lebih rendah dari teman- temannya yang lain. Dalam perkembangan kognitif siswa khususnya dalam mengenal angka, perlu sekali melakukan pengulangan di rumah agar pembelajaran di sekolah tidak berlalu begitu saja. Pengembangan kognitif siswa bukan hanya tugas seorang guru, melainkan juga orangtua yang ikut serta memberikan bimbingan dan pengulangan di rumah, sehingga siswa lebih mendalami pembelajaran yang diajarkan.

Sedangkan untuk subyek penelitian JO menunjukkan bahwa JO mengalami peningkatan yang signifikan karena ia mampu mengenal seluruh angka yang dapat dilihat pada grafik. JO merupakan satu-satunya subyek penelitian yang tidak dibantu mengerjakan lembar kerja seperti teman-temannya yang lain. Pengenalan angka terus mengalami peningkatan dari tindakan pertama sampai tindakan ketiga. Hal ini dapat dilihat melalui instrumen yang digunakan oleh peneliti yaitu umpan balik mentor, jurnal refleksi, lembar tes siswa dan wawancara.

Dalam setiap pengerjaan lembar kerja, KE juga dibantu untuk mengerjakan termasuk mengulang instruksi secara individual. Jika diakumulasikan dari keseluruhan tindakan, KE mampu mengenal angka 1-5. Peningkatan ini terjadi ketika penerapan media flashcard yang ketiga kalinya. KE mampu menjawab pertanyaan lisan yang diberikan oleh peneliti dan ketika mengikuti permainan flashcard, KE dapat bermain dengan baik sesuai dengan instruksi peneliti. Grafik menunjukkan

Wawancara dengan guru mentor dilakukan setelah selesai penerapan ketiga untuk mengetahui bagaimana peningkatan yang dialami siswa setelah media flashcard diterapkan. Hasil dari wawancara mengatakan penggunaan media flashcard membantu siswa dalam mengenal angka khususnya karena disajikan secara visualisasi. Selain itu, penggunaan media flashcard sudah dilaksanakan dalam beberapa pertemuan sehingga mereka dapat mengingat dan mengenali angka. Walaupun tidak semua siswa yang mengalami peningkatan, tetapi penggunaan media flashcard ini menjadi hal positif bagi anak. Guru mentor juga menjelaskan setiap anak mempunyai batas kemampuan masing-masing. Mungkin secara visual flashcard dapat membantu siswa mengenal angka, namun tidak dapat dipungkiri bahwa masih terdapat siswa yang belum mengalami perkembangan.

Setelah melakukan penelitian, peneliti menemukan berbagai faktor yang mempengaruhi siswa dalam mengenal angka 1-10. Berdasarkan penelitian yang dilakukan, motivasi memberikan pengaruh yang besar dalam hasil belajar (Husamah et al, 2018). Pemberian motivasi secara verbal sangat dibutuhkan oleh DA dan bukan hanya DA, tetapi juga siswa lain. Motivasi berupa verbal, video dan permainan flashcard merupakan satu bentuk yang dilakukan peneliti agar siswa mengikuti pembelajaran yang menyenangkan.

Dalam proses pembelajaran ada siswa yang dengan mudah mengerti apa yang diajarkan, ada juga siswa yang masih membutuhkan waktu untuk memahami materi pelajaran tersebut. Menurut Khodijah (2017) inteligensi seseorang sangat berpengaruh terhadap keberhasilan yang dicapainya dalam belajar. Inteligensi setiap anak berbeda-beda sehingga ketercapaiannya dalam belajar juga berbeda- beda. Selain itu, faktor lingkungan juga memiliki andil dalam perkembangan kognitif anak. Sekolah dan keluarga termasuk ke dalam faktor lingkungan. Di sekolah anak diajarkan untuk mengembangkan potensi yang dimilikinya untuk mempersiapkan kehidupan selanjutnya. Sekolah bekerjasama dengan orangtua di rumah untuk memberikan pengetahuan kepada anak. Agar anak dapat mencapai tingkat perkembangan yang optimal termasuk di dalam pendidikan, dibutuhkan keterlibatan orang tua untuk memberikan rangsangan secara konsisten melalui pembiasaan (Latif, 2013).

Pembiasaan dapat dilakukan dengan pengulangan, bahwa apa yang dipelajari di sekolah, orangtua bertanggungjawab untuk membimbing anak dalam mengulang pembelajaran. Pengaruh dan dukungan dari keluarga sangat dibutuhkan untuk membantu perkembangan anak. Khususnya ketika anak mengalami 
kesulitan dalam pembelajaran di sekolah, maka akan lebih efektif jika orangtua bekerjasama dengan guru di sekolah untuk mengulang pembelajaran. Kesibukan karena pekerjaan terkadang membuat orangtua kurang memperhatikan dan kurang memberikan waktu di dalam mengulang kembali pembelajaran. Seharusnya, orangtua yang menjadi pendidik utama dan mitra dalam mendukung keberhasilan pendidikan anak khususnya anak usia dini (Latif, 2013).

Selama melaksanakan tindakan yaitu media pembelajaran flashcard untuk meningkatkan kemampuan mengenal angka, peneliti menyadari banyak kekurangan yang terjadi. Namun lebih dari itu, peneliti melakukan penelitian ini dengan maksud memberikan pemahaman terhadap konsep dasar matematika yang sangat penting karena pasti dijumpai dalam kehidupan sehari-hari. Meskipun penelitian yang dilakukan tidak meningkatkan pengenalan angka secara keseluruhan terhadap subyek penelitian, namun peneliti sudah melakukan yang terbaik untuk membantu siswa. Setiap anak juga memiliki tahap perkembangannya masingmasing begitupun dengan keunikannya, sehingga peneliti yakin bahwa media flashcard dapat berguna dan merupakan hal yang positif bagi siswa.

\section{KESIMPULAN}

Kesimpulan berdasarkan penelitian yang telah dilakukan untuk menjawab rumusan masalah, yakni penggunaan media pembelajaran flashcard dapat meningkatkan kemampuan mengenal angka 1-10 siswa TK pada mata pelajaran matematika di salah satu sekolah di Manado. Peningkatan ini ditandai dari subyek penelitian yang mampu mengenal angka dari yang sebelumnya tidak mengenal angka sama sekali. Hal ini dapat dilihat melalui lembar kerja siswa, umpan balik mentor dan jurnal refleksi peneliti yang menjelaskan peningkatan mengenal angka 1-10 oleh masing-masing subyek penelitian.

Peningkatkan kemampuan mengenal angka 1-10 pada mata pelajaran matematika, dilihat dari langkah-langkah penggunaan media flashcard yang dilaksanakan selama 3 tindakan dan dimodifikasi dengan metode bermain sehingga menambah semangat siswa dalam mengikuti pembelajaran. Media flashcard dapat memudahkan siswa untuk memahami dan mengingat pembelajaran karena berisikan angka dan gambar yang sering dijumpai dalam kehidupan sehari-hari dan berkaitan dengan materi pembelajaran yaitu mengenal angka. Penggunaan media ini sebagai tanggungjawab seorang guru dalam memperbaiki masalah yang terjadi di dalam kelas. Hasil dari penelitian ini menyadarkan peneliti bahwa setiap anak mempunyai keunikan dan tingkat perkembangan yang berbeda-beda.

\section{DAFTAR PUSTAKA}

Chandra, R. D. A. (2017). Pengembangan Media Visual Kartu Angka Efektif Untuk Mengenalkan Huruf Vokal A, I, U, E, O Pada Anak Usia Dini 3-4 Tahun Paud Labschool Jember. Jurnal INDRIA (Jurnal Ilmiah Pendidikan Prasekolah Dan Sekolah Awal), 2(1).

Haslana, I., \& Wirastania, A. (2017). Mengembangkan kemampuan mengenal angka 1-10 melalui kartu angka pada taman kanak kanak kelompok A. Wahana: Tridarma Perguruan Tinggi, 69(2), 61-66.

Hatini, P. (2012). Peningkatan kemampuan matematika anak melalui media permainan memancing angka di Taman Kanak-kanak Fathimah Bukareh Agam. Jurnal Ilmiah Pesona PAUD, 1(1).

Husamah, Pantiwati, Y., Restian, A., \& Sumarsono, P. (2018). Belajar dan pembelajaran. Malang: Universitas Muhammadiyah Malang.

Jamaris, M. (2006). Perkembangan dan Pengembangan Anak Usia Taman. Kanak-kanak. Jakarta: Gramedia

Khadijah. (2016). Pengembangan kognitif anak usia dini. Medan: Perdana Publishing.

Khodijah, N. (2017). Psikologi pendidikan. Jakarta: Rajawali Pers.

Latif, M. (2013). Pendidikan Anak Usia Dini.Jakarta : Kencana Prenada. Media Group

Miswara, A., Wiyono, J., \& Ariani, N. L. (2018). Pengaruh Permainan Congklak Terhadap Peningkatan Kemampuan Berhitung Anak Usia 4-6 Tahun di TK Dharma Wanita Persatuan 02 Malang. Nursing 
News: Jurnal Ilmiah Keperawatan, 3(1).

Morrison .(2012). Dasar-dasarpendidikan anak usia dini (PAUD): Edisi 5. Jakarta: PT. Indeks.

Neolaka, A., \& Neolaka, G. A. (2017). Landasan pendidikan; dasar pengenalan diri sendiri menuju perubahan bidup. Depok: Kencana.

Nurseto, T. (2011). Membuat media pembelajaran yang menarik. Jurnal Ekonomi dan pendidikan, 8(1).

Rahman, T., \& Fuadatun, F. (2017). Peningkatan Kemampuan Anak Usia Dini Mengenal Konsep Bilangan melalui Media Flashcard. Jumal PAUD Agapedia, 1(1), 118-128.

Rofi'ah, S., Setyowati, A., \& Idhayanti, R. I. (2018). Media Gambar Flashcard Dalam Menstimulasi Perkembangan Bahasa Anak Usia 3-4 Tahun. Jendela Inovasi Daerah, 1(2), 78-92.

Stiawan, D., \& Mustaqimah, N. (2021). Pembelajaran Mengenal Konsep Bilangan Matematika pada Anak. CIRCLE: Jurnal Pendidikan Matematika, 1(02), 63-74.

Sujiono, Y. N. (2013). Konsep Dasar Pendidikan Anak Usia Dini. Jakarta. Indeks

Susanto, A. (2011). Perkembangan Anak Usia Dini. Jakarta: Kencana. Prenada. Media Group. 